\title{
HOW TO VALUE EQUITY IN NATIONAL ACCOUNTS?
}

\author{
JANA KRAMULOVÁa, ${ }^{\mathrm{a}, \mathrm{b}, *}$, JAKUB VINCENC ${ }^{\mathrm{b}}$, HELENA HOUŽVIČKOVÁ $^{\mathrm{b}}$ \\ jana.kramulova@vse.cz,jakub.vincenc@czso.cz, helena.houzvickova@czso.cz
}

\author{
a University of Economics in Prague, Faculty of Informatics and Statistics, Department of Economic Statistics, \\ W. Churchill Sq. 4, Prague, Czech Republic \\ b Czech Statistical Office, Financial Accounts Unit, Na padesátém 81, Prague, Czech Republic
}

\begin{abstract}
The objective of national accounts is to present a model of the real economy in the most accurate way. It means that not only officially recorded data from business accounting are included, but also model computations are used (e.g. in estimating the size of the shadow economy or correcting a phenomenon that may be biased in data sources). This is the reason why there sometimes exist vast differences between national accounts and business accounts. One of those most challenging fields is financial item AF.51, equity, whose valuation is considered differently in national and business accounts. Moreover, equity has close relationship with net worth of enterprises and this topic has recently been broadly discussed among national compilers. The aim of this paper is to show and compare possible methods of equity valuation and to emphasize its relationship to revaluation of non-financial assets made in national accounts under the ESA 2010 manual. The paper highlights the worldwide initiative of the Czech Statistical Office in the field of equity valuation that results in the proposal of a new methodology of equity valuation, with an effort to stir up a debate about this topic. It also makes a comparison of preliminary results in order to demonstrate potential changes in recognizing equity in national accounts.
\end{abstract}

\section{Key words}

equity, net worth, valuation, national accounts

\section{JEL classification}

E44, G20, O16

\section{Introduction}

The target of national accounts is to describe the model of a proper economy in the most accurate and complex way. It means that not only officially recorded data from business accounting are included, but also model computations are used; e.g. to estimate shadow economy or phenomenon that may be biased in data sources.

The methodology of national accounts in Europe is covered in extensive manual entitled European System of Accounts ESA 2010 (European Commission and Eurostat, 2013). This manual includes 24 detailed chapters that describe different parts of national accounts from different points of view and set the rules for their compiling. Among these areas are such aimed at financial transactions (Chapter 5) or financial assets and liabilities (part of Chapter 7) that are the most relevant for this paper.

The economy changes in time and it is quite challenging for national accounts to describe economy in right numbers and capture all these new effects properly. That is the reason why there sometimes exist vast differences between national accounts and business accounts. One of those most challenging fields is financial item equity, whose valuation is considered differently in national and business accounts. We will discuss this topic in more detail in Section 4.1. Equity (in national accounts coded AF.51) is one of financial assets, apart from e.g. currency, deposits, securities, loans and many others. The complete list of financial assets 
can be found in European Commission and Eurostat (2013, p. 521 and following). Equity and its valuation will be discussed in more detail in Section 3.

Let us only emphasise that equity can be found on assets as well as liabilities side of national accounts. "It is, however, excluded from the various definitions of "debt"." (OECD, 2017 , p. 28). We will in this paper consider only the larger, liabilities side of institutional sector of non-financial corporations (hereinafter labeled as S.11), that is further divided into public non-financial corporations (S.11001), national private non-financial corporations (S.11002) and foreign controlled non-financial corporations (S.11003). Liabilities side actually stands for shares of non-residents in Czech non-financial corporations (i.e. external owner of corporate shares). The asset side, i.e. share of Czech households on foreign companies, is not taken into account.

Moreover, equity has a close relationship to net worth of enterprises and this topic has recently been broadly discussed among national compilers. Net worth is a part of national wealth that is in detail discussed by Ondruš (2015). He also states that the computation of national wealth is developing in time and that the Czech Statistical Office (hereinafter CZSO) is "improving the quality and completeness of the quantification of the national wealth" and "this process is not completely finished." (Ondruš, 2015, p. 5). This development can be seen also in the fact that Sunga (1987) takes into account when computing net worth only house, bonds, mortgage and short-term loans. Net worth is an important indicator in national accounts and is published in Czech national accounts since 1993 (Ondruš, 2015, p. 4), however, CZSO "publishes time series of macroeconomic aggregates starting in 1990" (Sixta and Fischer, 2014, p. 177). Net worth will be introduced in Section 2.

Aim of this paper is to show and compare the possible methods of valuation of equity and to emphasise its relationship to revaluation of non-financial assets made in national accounts under ESA 2010 manual.

The paper is organised as follows: Section 2 presents the relation of net worth of a company to equity. Section 3 provides information about various approaches to valuation of equity in national accounts. Section 4 introduces interesting differences in the field of equity, firstly between business and national accounting and secondly between two main manuals, ESA 2010 and BPM 6. Section 5 shows various adjustments of equity made in national accounts. In Section 6 we discuss novelty in the field of equity in the benchmark revision of the Czech Statistical Office that will occur in June 2020. Section 7 is devoted to conclusion.

\section{Net worth of a company versus equity}

What is the net worth of a company? This is one of the hardest questions in national accounts. We "conclude that companies' net worth using business accounting equals current year profits because at the point it has not been decided yet, whether those profits will be paid out as dividends or reinvested into the enterprise. In this case, the owners' share in the enterprise is increased. Furthermore, we include in net worth any mandated reserve funds that cannot be paid out" (Kermiet and Houžvičková, 2018, p. 8-9).

In the national accounts under manual ESA 2010 net worth is the balancing item on the balance sheet for institutional sectors, i.e. the difference between assets and liabilities. "The stock of the assets and liabilities recorded in the balance sheet are valued at the appropriate prices, which are usually the market prices prevailing on the date to which the balance sheet relates, but for some categories at their nominal values" (European Commission and Eurostat, 2013 , p. 200). It means that assets and liabilities in national accounts are not at the same value as in business accounting, e.g. businesses valued non-financial assets at acquisition cost, and the national accounts value these assets at current prices. At the same time "the definition of non-financial assets is different, with national accounts including capitalization of $\mathrm{R} \& \mathrm{D}$, small tools and military equipment etc. However, these additional assets currently do not have 
corresponding treatment on the liabilities side, leading to a significant overvaluation of enterprises' net worth instead of the net worth of owners" (Kermiet and Houžvičková, 2018, p. 8-9).

In the opinion of Czech national compilers, this should be somehow reflected on liabilities side. The only option is to treat it as changes in enterprise's equity. The definition of equity by ESA 2010 says, that "[e]quity is a financial asset that is a claim on the residual value of a corporation; after all other claims have been met" (European Commission and Eurostat, 2013, p. 176). For listed shares, manual ESA 2010 states that revaluated value of equity is "adopted for both the asset side and the liability side, although shares and other equity are not, legally, a liability of the issuer, but an ownership right to a share in the liquidation value of a corporation, where the liquidation value is not known in advance" (European Commission and Eurostat, 2013, p. 209). This statement should be applicable for other revaluation of assets. "Therefore, the definition says that equity should be evaluated as a share in the liquidation value of a corporation" (Ondruš, 2015, p. 9). Liquidation value of a corporation is equal to assets minus liabilities less net worth estimated in the national accounts. It is mentioned above, that net worth in business accounting is defined as current year profits. In the concept of national accounts, adjusted current profits correspond to net disposable income.

\section{Various approaches to valuation of equity in national accounts}

Equity (hereinafter AF.51) is in the manual ESA 2010 described as a part of "financial assets that represent property rights on corporations or quasi-corporations. Such financial assets generally entitle the holders to a share in the profits of the corporations or quasicorporations, and to a share in their net assets in the event of liquidation" (European Commission and Eurostat, 2013, p. 219).

Equity is divided into three main groups:

- listed shares (AF.511);

- unlisted shares (AF.512);

- other equity (AF.519).

As mention above, equity should be valued as other financial assets at the appropriate prices, which are usually the market prices. The manual ESA 2010 and Financial Handbook both define rules for valuation of each item of AF.51.

"Listed shares (AF511) are valued at their current prices" (United Nations Statistics Division and European Central Bank, 2014, p. 342). The current prices represent the market value.

"Unlisted shares (AF512), which are not traded on organized markets, should be estimated with reference to either:

a) The values of quoted shares where appropriate;

b) The value of own funds; or

c) Discounting forecast profits by applying an appropriate market price to earnings ratio to the smoothed recent earnings of the institutional unit" (United Nations Statistics Division and European Central Bank, 2014, p. 343).

"Other equity (AF.519) is equity that is not in the form of securities. It can include equity in quasi-corporations (such as branches, trusts, limited liability and other partnerships), public corporations, unincorporated funds and notional units (including notional resident units created to reflect non-resident ownership of real estate and natural resources). The ownership of international organizations not in the form of shares is classified as other equity. Quasicorporations' other equity is valued according to their own funds, since their net worth is by convention equal to zero. For other units the most appropriate valuation method from the 
methods used for unlisted shares should be taken" (European Commission and Eurostat, 2013, p. 209).

In the national accounts of the Czech Republic, equity is valued upon a methodology mutually agreed with the Czech National Bank (hereinafter CNB). The CZSO is responsible for compiling of annual financial accounts whereas the CNB compiles quarterly financial accounts (apart from government sector which is compiled by the CZSO). That is the reason for necessity of harmonisation of both outcomes, as quarterly values should equal national values. "Listed shares are valued at market prices, with the number of shares listed on the Prague Stock Exchange multiplied by their current quotation" (Kermiet and Houžvičková, 2018 , p. 4). Value of unlisted shares is based on own funds method. "Other equity in the Czech Republic is most often in the form of limited companies. Limited companies are recorded using the value of their own funds in their accounts. These are obtained from a multi-pronged census of the companies, including surveys by the CNB (including the Balance of payments), statistical survey by CZSO and the publicly accessible database BISNODE (an administrative source that takes its data from tax returns). It was first necessary to determine which organisational forms to survey. Next, appropriate data sources needed to be identified. In some cases, a companies' data can be found in more than one source" (Kermiet and Houžvičková, 2018, p. 5).

Table 1 below shows the structure of equity in the Czech Republic on the liabilities side in non-financial corporations (S.11) in the year 2016. We can see, that the proportion of other equity is slightly higher than the proportion of unlisted shares, whereas the proportion of listed shares is insignificant.

Table 1: Structure of equity (AF.51) for non-financial corporation for 2016 (in CZK mil. and $\%)$

\begin{tabular}{ccc}
\hline AF.51 & Value & Share \\
\hline Listed shares (AF.511) & 388954 & $7 \%$ \\
Unlisted shares (AF.512) & 2271323 & $40 \%$ \\
Other equity (AF.519) & 2971816 & $53 \%$ \\
Total & 5632093 & $100 \%$ \\
\hline
\end{tabular}

Source: data from the Czech National Bank.

\section{Interesting differences in the field of equity}

There are more perspectives that can be applied on equity in national accounts. Following two subsections deal with the two main views.

\subsection{National and business accounting}

As ESA 2010 state in Chapter 21, ,[n] ational accounting shares with business accounting a number of characteristics, the most noticeable of which are: a) the recording of transactions in accounts, i.e. in two-column tables, b) monetary valuation, c) use of balancing items, d) recording of transactions as they take place, and e) internal coherence of the system of accounts." (European Commission and Eurostat, 2013, p. 486).

However, between both approaches are also several distinctions. We have already stated some of them in Section 2. One distinction between business and national accounting is in valuation of non-financial assets (at acquisition cost versus at current prices). Apart from valuation $\operatorname{OECD}(2017$, p. 206) mentions coverage problem. "For example, some assets are recognised in the national accounts which are not recorded as such in business accounting, such as intellectual property products. On the other hand, in the case of business accounts some provisions for future expenses may be deducted from the owners' equity." 
Another difference, also already mentioned, is the approach to net worth (in business accounting as current year profits, in national account as net disposable income). If we look more closely on net worth, we can analyse two equations (for details see OECD, 2017, p. 205). Business accounting operates with identity

$$
\text { Total assets }=\text { Total debt liabilities }+ \text { Owners' equity, }
$$

whereas national accounts proceed with equation

$$
\begin{gathered}
\text { Total assets }=\text { Total liabilities (including outstanding equity at market prices) } \\
+ \text { Net worth (i.e. any remaining residual). }
\end{gathered}
$$

OECD (2017, p. 205) further discusses: "Note that when total assets are equal to total liabilities in the SNA, there is no residual net worth of the non-financial corporations' sector. Furthermore, if stock market prices are particularly high, in view of investors' future profit expectations, then residual net worth may even become negative."

The other difference that should be considered is the fact, that national accounting is standardised across the world (see Section 4.2 about ESA and SNA manual), whereas business accounts have national specifics. ESA 2010 manual, however, reminds IFRS (International Financial Reporting Standards), that could harmonise business accounts as well, but this will be a longer journey.

\subsection{ESA 2010 (SNA 2008), Financial Handbook and BPM 6}

There are two main worldwide manuals dealing with financial assets. One branch is the line of national accounts, i.e. manuals aimed at national statistical institutes. The manual dedicated for all countries in the world is SNA 2008 (European Commission et al., 2009). The version adapted for the European Union and European countries, slightly different from SNA 2008, is manual ESA 2010 (European Commission and Eurostat, 2013). The Eurostat surveils conformity of national accounts with this manual. Another manual, dealing directly with financial accounts is so called Financial Handbook, i. e. Financial Production, Flows and Stocks in the System of National Accounts manual (United Nations Statistics Division and European Central Bank, 2014).

The second branch is represented by the sixth edition of the Balance of Payments and International Investment Position manual (hereinafeter BPM 6) which is the main manual for the national banks under the supervision of International Monetary Fund (see International Monetary Fund, 2014). Its proper use is monitored also by the European Central Bank. The methods of approximating of equity market value are available in International Monetary Fund (2014, paragraph 7.16 and following).

Sometimes differences between interpretation of some concepts occur. One of such examples are reinvested earnings, which will be discussed in Section 6. BPM 6 is based on business accounting and "specifies the use of book value for shares of unlisted entities and market value for shares of listed entities." (Kermiet and Houžvičková, 2018, p. 9-10). CZSO uses principles of national accounting and that is why reinvested earnings computation in CZSO and CNB may differ.

\section{Adjustments of equity made in national accounts}

Some adjustments have to be made, because business accounting does not give us all of the information needed. This is also the reason of the differences between these two account systems. See the following adjustments to understand why they are necessary for completion of the national accounts. 


\subsection{Notional units}

Let us have a look on this adjustment from the liabilities side only, where it represents the holding of dwellings and land by non-residents in the Czech Republic. The stock of dwellings is based on their quantity and average prices, which are influenced by type of dwelling and by relevant region, it is located in. In case of land the value depends on its area and soil type. The whole adjustment makes up about $3 \%$ of equities in AF.519.

Figure 1 below shows increasing value of notional units in the Czech Republic. It is mainly caused by growing numbers of flats in Prague owned by non-residents and their growing price especially in the year 2017.

\subsection{Housing cooperatives}

Housing cooperatives are created to provide dwellings services to their members and housing cooperatives are also the owners of dwellings. Householders own just a share in the cooperatives and their share is estimated by another assumption, which is quite important, because it makes up about $10 \%$ of equities in AF.519.

The estimation is not simple in the situation when accounting of housing cooperatives does not provide direct information that can be used for this computation. "By business accounting they are evaluated in the amount of initial deposits to the cooperative. The actual market value of the flats, however, is much higher due to the general trend of prices of real estate, and, in particular, therefore, that cooperative financed flats from deposits by members, but also by subsidies and loans, or due to privatisation of municipal flats for significantly lower price than their market value. For these reasons, we correct the data taken from accounts of housing cooperatives, and the participation of the members in cooperatives we evaluate by the market value of flats reduced by taken loans." (Ondruš, 2015, p. 9).

Figure 1: The value of dwellings and land owned by non-residents in the Czech Republic since 2010 (in millions of CZK)

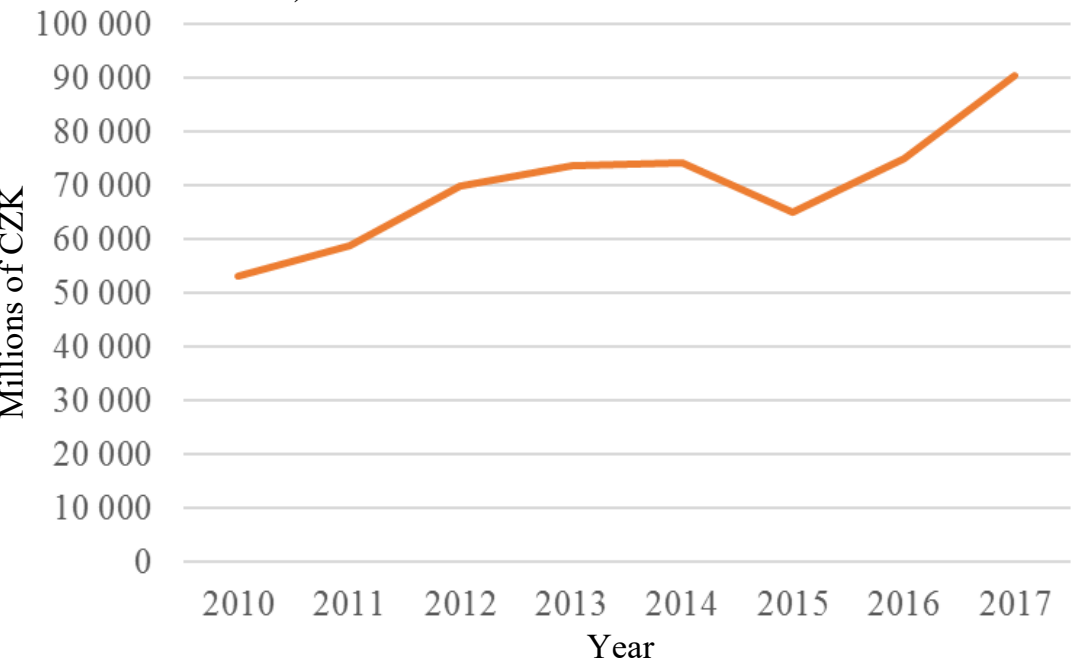

Source: the authors based on data from Czech Statistical Office.

In this case, "[f]or the calculation of the stock of fixed assets, the perpetual inventory method (PIM) is applied whenever direct information on the stock of fixed assets is missing." (European Commission and Eurostat, 2013, p. 76). PIM method is based on revaluation of investments into market prices and on estimation which part of the investments will be in balance sheet in the end of the year. Detailed explanation of PIM can be found also in Krejčí and Sixta (2012). 


\subsection{Forests}

This adjustment is again based on the difference between business accounting and approach of national accounts. Whereas business accounts cover only the value of land, national accounts include also the value of the trees, that are perceived as timber. ESA 2010 (European Commission and Eurostat, 2013, p. 207) in paragraph 7.48 state that "[s]tanding timber is valued by discounting the future proceeds of selling the timber at current prices after deducting the expenses of bringing the timber to maturity, felling, etc.". The estimate of CZSO is based on complex balance of forests in physical units with the recalculation into monetary units using data from price statistics and forestry statistics.

\subsection{Reinvested earnings}

Reinvested earnings are a part of undistributed profits in companies, which belong to foreign direct investors in proportion to their ownership interest in the company. These profits are then reinvested through a capital equity and increase in the financial account. Reinvested earnings on foreign direct investment (RIE) can be both positive and negative.

Reinvested earnings were present already in ESA 1995 manual, previous to ESA 2010 (see Dalgaard et al., 2000, for ESA 1995 and SNA 1993 discussion). Piketty et al (2018, p. 569) state that "allocating retained earnings proportionally to equity wealth is a reasonable benchmark".

Profits on foreign direct investment in the balance of payments are based on the data from business accounts; while for the national accounts are based on national accounting. The main differences between both methods are mainly in the definition of profit because the profit in business accounting includes also financial gain. Other differences result from the adjustments of the methodology ESA 2010, which is non-exclusion of holding gains, capitalisation of expenditure on research and development, as well as consumption of fixed capital and other methodological adaptations. Calculation based on the data from corporate accounting distorts macroeconomic view, because it excludes a number of adjustments, which in turn reflects better the logic of national accounts.

Reinvested earnings represent the value of retained earnings in units with foreign participation, which in the form of dividends were not transferred abroad. These profits can be taken as primary income outflow, which reduces the disposable income.

Reinvested earnings on foreign direct investment (in national accounts coded as D.43) are defined in paragraph 4.64 of manual ESA2010 (European Commission and Eurostat, 2013, p. 102). They are computed according to equation

$$
\begin{aligned}
& D .43=B .2 n+D .1 r+D .2 r+D .3 r+D .4 r+D .5 r+D .61 r+D .62 r+D .7 r-D .4 u- \\
& D .5 u-D .61 u-D .62 u-D .7 u,
\end{aligned}
$$

where $D .43$ stands for reinvested earnings on foreign direct investment, $B .2 n$ for net operating surplus of the foreign direct investment enterprise, $D .1 r, D .2 r, D .3 r, D .4 r, D .5 r, D .61 r, D .62 r$, $D .7 r$ for any property incomes or current transfers receivable, i.e. on the resource side (for detailed information on all the codes see European Commission and Eurostat, 2013, p. 511 and following), and $D .4 u, D .5 u, D .61 u, D .62 u, D .7 u$ for any property incomes or current transfers payable, including actual remittances to foreign direct investors and any current taxes payable on the income, wealth, etc., of the foreign direct investment enterprise.

\subsection{Adjustments connected with revision from manual ESA 1995 to ESA 2010}

ESA 2010 manual brought some new adjustments especially in area of capitalisation. Since its entry to force, capitalisation of small tools, research and development or military equipment was added into national accounts estimates. All these three adjustments are 
described in European Commission and Eurostat (2014) and from CZSO point of view also in Musil and Cihlář (2016) and Sixta (2014).

The main novelty common for all three types of adjustments stands in the fact, that these adjustments increase the value of non-financial assets, so far without impact on the liabilities side, i.e. with the whole value raising net worth.

Table 2 shows the increase in equity resulting from different adjustments made in national accounts solely on the asset side in non-financial accounts. The main increase in S.11 is from adjustment of the forests and small tools.

Table 2: Increase in equity resulting from adjustments made in national accounts (in \%)

\begin{tabular}{cc}
\hline Adjustment & Increasing of equity (\%) \\
\hline Housing cooperatives & 6 \\
Research and development & 4 \\
Small tools & 7 \\
Software & 0 \\
Forests & 11 \\
Total & 28 \\
\hline
\end{tabular}

Source: the authors.

\section{Novelty in the field of equity in the benchmark revision of the Czech Statistical Office in June 2020}

CZSO is going to implement new item called AF.51n (equity and other shares - national accounts concept) in the benchmark revision being published in June 2020. This item will contain differences between CZSO approach and approach of the CNB in valuation of equity. The CNB so far accepts the recording of housing cooperatives and notional units as equity. "There remain differences of opinion on including capitalisation of research and development expenditures outside of companies' accounts, on capitalisation of small assets and possibly most importantly on revaluation of fixed assets." (Kermiet and Houžvičková, 2018, p. 9). Because of this novelty, the stock of equity in AF.51 will be fully harmonised with CNB.

At first, new item AF.51n will contain the differences between RIE calculation based on business accounts, which is used by $\mathrm{CNB}$, and RIE calculation based on national accounts. One of the reasons why the CZSO has to use different way of calculation is that when you use "only business accounts profit without any proper adjustment. This distorts GNI and overvalues the national wealth". (Kermiet and Houžvičková, 2018, p. 7). Table 3 shows the exact numbers of the differences caused by RIE.

Table 3: The difference between two approaches of computation reinvested earnings (in millions of CZK)

\begin{tabular}{lccccccc}
\hline & 2010 & 2011 & 2012 & 2013 & 2014 & 2015 & 2016 \\
\hline RIE by CZSO & 91230 & 99130 & 96811 & 78172 & 146777 & 143020 & 128812 \\
RIE by CNB & 75921 & 38008 & 81706 & 95298 & 63233 & 75920 & 66969 \\
Difference & 15309 & 61122 & 15105 & -17126 & 83544 & 67100 & 62539 \\
\hline
\end{tabular}

Source: the authors and data from the Czech National Bank.

Background of the second adjustment has already been discussed in Section 2 and the calculation of the revaluation of liabilities that have to be distributed to owners will be done using equation 4 below (Kermiet and Houžvičková, 2018, p. 9).

$$
A F .51 n=B .90-(B .6 n+\text { mandatory reserves })-A F .51-A F .52 \text {, }
$$

where:

- AF.51n stands for revaluation of liabilities,

- $B .90$ for net worth (i.e. assets less liabilities), 
- B.6n for net disposable income and mandatory reserves,

- AF.51 for equity as valued by the Czech National Bank and

- AF.52 for other shares as valued by the Czech National Bank (for detailed information on all the codes see European Commission and Eurostat, 2013, p. 511 and following).

In Table 4 you can find out preliminary result of revaluation liabilities in S.11. The data were computed for year 2016.

Table 4: Preliminary results of revaluation of liabilities S.11 in 2016 (in millions of CZK)

\begin{tabular}{lcccc}
\hline & S.11001 & S.11002 & S.11003 & S.11 total \\
\hline AF.51 & 648827 & 2607993 & 2375273 & 5632093 \\
AF.51n & 1595289 & 1220461 & 421453 & 3237203 \\
AF51 total & 2244116 & 3828454 & 2796726 & 8869296 \\
\hline
\end{tabular}

Source: the authors.

In comparison of these values with the total value of equities in AF.51 in Table 1 we find out that this adjustment will significantly increase the value of equity in S.11. The value of AF.51n is still subject to change under the conceptual adjustments and balancing process, which will be made in the following revision of national accounts. That is why we present these values as preliminary results. The final ones will be available in June 2020 together with publication of benchmark revision of national accounts.

This increase of the value of equity in S.11 could be the main problem. Especially, in relationship to non-residents due to its impact to balance of payment. "Introducing a new method would disrupt international comparisons such as country asymmetries and the net IIP to GDP ratio, which is one of the leading macroeconomic imbalance procedure indicators. This is just one of the reasons the new calculation will be presented as a memo item rather than as a part of the standard indicators reported to international institutions." (Kermiet and Houžvičková, 2018, p. 9-10).

\section{Conclusion}

The paper brings the discussion about differences of valuation of equity between business accounts and national accounts. The main point is the measuring of the net worth that represents wealth of each sector. If revaluation of assets made in the national accounts is not reflected to equity, the net worth of corporations will be higher and higher. It means that companies (S.11) become richer in comparison with their owners. This article tries to emphasise the amount of revaluation and brings possible solution of this problem. It shows the worldwide initiative of the CZSO in the field of equity that results in the proposed new methodology of valuation of equity and effort to stir up a debate about this topic. It also presents the comparison of preliminary results in order to demonstrate the potential change in grasp of equity in national accounts.

The new methodology of item AF.51n indicates the so far existing problem with harmonisation of data from national accounts with balance of payment; that is why it remains as memo item. Moreover, it is not possible that the Czech Republic alone includes this item into national accounts. This effort of the CZSO can in future after debates with other countries and relevant institutions possibly result in changes in global methodology of valuation of equity. It is necessary to give rise to a discussion to harmonise the data worldwide. Due to the relation of equity with balance of payment this change in valuation affects also so called asymmetry among countries, i.e. if there is any transaction between e.g. the Czech Republic and Germany, it should be recorded in the same sense in mirror image in the national accounts of both countries. Moreover, it influences also some of the leading macroeconomic imbalance procedure (MIP) indicators that have recently been largely monitored by Eurostat and ECB. 
Subsequent research and work will be aimed especially at the procedure how to distribute the revaluation of liabilities to their owners on the asset side. The main challenge is to collect information about beneficial owners particularly from government sector, households and non-residents.

\section{Acknowledgements}

This paper was supported financially by the Czech Statistical Office.

\section{References}

[1] Dalgaard, E., Eff, C., Thomsen, A. 2000. Reinvested earnings in the national accounts. In Review of Income and Wealth, 2000, vol. 46, iss. 4, pp. 401-419.

[2] European Commission and Eurostat 2013. European system of accounts ESA 2010. Luxembourg: Publications Office of the European Union, 2013. ISBN 978-92-79-31242-7.

[3] European Commission and Eurostat 2014. Manual on the changes between ESA 95 and ESA 2010. Luxembourg : Publications Office of the European Union, 2014. ISBN 978-92-79-37839-3.

[4] European Commission et al. 2009. System of national accounts 2008. New York : United Nations. ISBN 978-92-1-161522-7.

[5] International Monetary Fund 2014. BPM6 compilation guide. Washington, D.C.: International Monetary Fund, 2014. ISBN 978-1-48437-271-5.

[6] Kermiet, V., Houžvičková, H. 2018. Distribution of wealth, correct treatment across institutional sectors. Meeting of the Working Party on Financial Statistics, 5 Nov 2018, OECD Conference Centre. [cit. 2019-03-18] http://www.oecd.org/officialdocuments/ publicdisplaydocumentpdf $/$ cote $=\mathrm{COM} / \mathrm{SDD} / \mathrm{DAF}(2018) 3 \&$ docLanguage $=$ En .

[7] Krejčí, I., Sixta, J. 2012. Využití alternativních metod při odhadech stavů a spotřeby fixního kapitálu. In Politická ekonomie, 2012, vol. 60, iss. 6, pp. 780-800.

[8] Musil, P., Cihlár, M. 2016. Impact of the implementation of ESA 2010 on volume measurement. In Statistika: Statistics \& Economy Journal, 2016, vol. 96, iss. 2, pp. 5-14.

[9] OECD 2017. Understanding financial accounts. Paris : OECD Publishing, 2017. ISBN 978-92-64-28128-8.

[10] Ondruš, V. 2015. Accounting for wealth in the Czech Republic. In Statistika: Statistics \& Economy Journal, 2015, vol. 95, iss. 1, pp. 4-18.

[11]Piketty, T., Saez, E., Zucman, G. 2018. Distributional national accounts: Methods and estimates for the United States. In Quarterly Journal of Economics, 2018, vol. 133, iss. 2, pp. 553-609.

[12] Sixta, J. 2014. Development of the measurement of product. In Statistika: Statistics \& Economy Journal, 2014, vol. 94, iss. 4, pp. 73-84.

[13] Sixta, J., Fischer, J. 2014. Using input-output tables for estimates of Czech gross domestic product 1970 - 1989. In Economic Systems Research, 2014, vol. 26, iss. 2, pp. 177-196.

[14] Sunga, P. S. 1987. Adjusting net worth for price changes with reference to the Canadian system of national accounts. In Review of Income \& Wealth, 1987, vol. 33, iss. 1, pp. 83-108.

[15] United Nations Statistics Division (UNSD) and European Central Bank (ECB) 2014. Financial production, flows and stocks in the system of national accounts. New York: United Nations. 2014. ISBN 978-92-1-161577-7. 